\title{
ASSESSING UNIVERSITY RESEARCH PERFORMANCE WITH MULTIPLE CONSTITUENCIES
}

\author{
Kuang-Liang Liu \\ Chung Hwa University of Medical Technology \\ No.89, Wenhwa 1st St., Rende Shiang, Tainan County 717, Taiwan, R.O.C. \\ klliu@mail.hwai.edu.tw \\ Chen-Chi Chang \\ National United University \\ No.1, Lienda, Miaoli County 360, Taiwan, R.O.C. \\ kiwi@nuu.edu.tw
}

\begin{abstract}
The research performance of a university is critical to national competitiveness. Previous research has established that research performance is based on scholarly publishing. Several studies suggest that journal ranking is an important research quality indicator. However, unilateral measurement for research performance will seriously corrode the development of university research work. Assessing university research performance with multiple constituencies is a better way to enhance research. Although substantial studies have been performed on the critical factors that affect knowledge exploration in the university, those in knowledge exploitation are still lacking. With multiple constituencies, a fully understanding of research performance can be gained. In the research model, knowledge exploration represents the academic research and knowledge exploitation represents the university-industry collaboration. Data were collected from 124 university data in online database. The study shows that knowledge exploration and exploitation are significant positive predictors of university
\end{abstract}


competitiveness. University resources play important roles affecting both knowledge exploration and exploitation in the university. The study also shows that higher knowledge exploration will enhance knowledge exploitation. Implications for theory and practice and suggestions for future research are discussed.

Keywords: Research Performance, Multiple Constituencies, University-Industry Collaboration, Resource-Based Theory, Resource-Dependence Theory

\section{INTRODUCTION}

Countries around the world face the challenge of maintaining a competitive position in the global economic environment. Economic and cultural globalization has ushered in a new era in higher education. National competition and global competition are distinct but connected with each other (Marginson, 2006). With the globalization of economy, university research performance has become an important support for industry as an element of both products and production processes over the last few decades. The ability of universities is often seen as a source of technology development that is useful to economic activity (Mowery, Nelson, Sampat, \& Ziedonis, 2001; Rosenberg \& Nelson, 1994). University research performance to efficiently produce high quality knowledge has become an important indicator of national competence.

Universities are key components of the economy, because they create knowledge and disseminate it to industry and wider society. Because of the strategic significance of universities, research performance and cost-effectiveness have become highly relevant issues to the government. As a result, there is a strong science policy trend that emphasizes the research performance of the university sector. Competition for money and other financial incentives are often used as steering instruments, since funding is regarded as having a strong impact on the behavior of universities, which are dependent on resources from other organizations such as state agencies (Himanen, Auranen, Puuska, \& Nieminen, 2009). Consequently, governments have started to implement mechanisms for allocating resources that relate funding to some measure of university research output or performance. However, mechanisms for research evaluation are not uniform across countries. Also, the long-term usefulness and impacts of funding incentives and competition on university research are still unclear. 
This study suggests that universities should move towards technology-oriented research missions and establish closer interaction with enterprises. University research strives to meet two goals: knowledge exploration through academic research and knowledge exploitation through university-industry collaboration. Explaining variation in performance or effectiveness is one of the more enduring themes in the study of organizations (March \& Sutton, 1997). However, studying organization-level performance is problematic because of the multiple constituencies which organizations serve (Zammuto, 1984; Tsui, 1990). Multiple constituencies mean that organizational purpose can be portrayed as unitary or that the multiple purposes of an organization are reliably consistent (March \& Sutton, 1997). The lack of measures of organizational performance to reflect an organization's multiple constituencies may lead the organization to treat satisfaction of its constituencies as the primary goal (March \& Sutton, 1997). From a resource dependence perspective (Pfeffer \& Salancik, 1978), this could lead to alienation of important constituencies and eventual demise of the organization.

Previous research (Trieschmann, Dennis, Northcraft, \& Niemi Jr, 2000) has only focused on research performance and MBA program performance. This study extents the research by including the number of patent, industry funding and federal government funding for knowledge exploitation. This paper analyses different resources to improve research performance in universities and how they relate to the allocation of government research funds. This study finds that both university-industry collaboration and academic publishing are needed and should be stressed in research performance.

\section{THEORETICAL BACKGROUND AND HYPOTHESES}

The resource-based view and resource-dependency theory receive great attention in the strategic management literature (Hillman, Withers, \& Collins, 2009; Peteraf, 1993; Priem \& Butler, 2001; Wernerfelt, 1984). Internal resources include human capital resources, financial resources, technology, plant and equipment, innovative abilities and internal processes systems, all of which are directly under the control of an organization that can influence it (Nemati, Bhatti, Maqsal, Mansoor, \& Naveed, 2010). This study aims to explain the relationship of different capital resources and human resources that affect research performance. The study draws on both the resource-based theory and the resource dependence theory to investigate the influence of knowledge exploitation and knowledge exploration on research performance in universities. 
The resource-based theory and resource-dependence theory are useful for understanding research performance in universities for several reasons. The resource-based view provides an economic tool to determine the strategic resources available to an organization, while the resource-based theory helps to identify potential key resources for improving research performance. The resource-based view explains a university's ability to reach sustainable competitive advantage when different resources are employed that cannot be imitated by competitors, which ultimately creates a competitive barrier. Moreover, resource-dependence theory (Pfeffer \& Salancik, 1978) suggests that attention paid to a constituency should reflect the organization's reliance on that constituency for resources. This implies that private schools, which are more dependent on funding projects for resources, should devote more time and effort to this constituency through exploitation of knowledge. From a resource dependence perspective, this could lead to alienation of important constituencies and the eventual demise of the organization (Trieschmann et al., 2000).

\section{Resource-based Theory}

Resource-based theory views the firm as a bundle of resources and capabilities (Birger, 1984). A university is a professional organization (Mintzberg, 1989) which is similar to a firm and also looking for competence in the global economic environment. University resources consist of tangible components (financial and physical assets) and intangible components (human capital) (Grant, 1991; Raphael \& Schoemaker Paul, 1993). Resource-based theory argues that universities will have different types of resources and varying levels of capabilities. A university's competence depends on its ability to create new knowledge, build on its capabilities platform, and make the capabilities more inimitable to achieve competitive advantage.

In the global economic setting, the need for corporation between universities and industries has increased. This study proposed that the increased interaction between science and industry can be explained from a resource-based view (Penrose, 1995) and to some extent from a multiple constituencies perspective. According to the resource-based view, universities integrate knowledge and other resources to create organizational capabilities in order to gain a competitive advantage (Barney, 1991). Universities' activities are shaped by a strategic balance between exploration and knowledge exploitation (March, 1991). 


\section{Resource-dependence Theory}

Resource dependence theory (RDT) has implications regarding the optimal divisional structure of organizations, recruitment of board members and employees, production strategies, contract structure, external organizational links, and many other aspects of organizational strategy. RDT is one many theories in organizational studies. In many ways, the predictions of RDT are similar to those of transaction cost economics, but it also shares some aspects with institutional theory. Organizational success in RDT is defined as organizations maximizing their power (Pfeffer, 1981). RDT characterizes the links among organizations as a set of power relations based on exchange resources. RDT proposes that actors lacking in essential resources will seek to establish relationships with others in order to obtain needed resources. Organizations attempt to alter their dependence relationships by minimizing their own dependence or by increasing the dependence of other organizations on them. From this perspective, organizations are viewed as coalitions alerting their structure and patterns of behavior to acquire and maintain needed external resources. Acquiring the external resources needed by an organization comes by decreasing the organization's dependence on others and/or by increasing other's dependence on it, that is, modifying an organization's power with other organizations.

\section{RESEARCH MODEL AND HYPOTHESES}

By integrating the two resource theories presented above, a research model is proposed that aims to understand the critical factors affecting knowledge exploration and knowledge exploitation in the university. This study suggests that research performance can be affected by both knowledge exploration and knowledge exploitation (Figure 1). This study selected university resources depend on whether these resources fulfill the following criteria: valuable, rare, inimitable, and non-substitutable. University resources include all assets, capabilities, information, knowledge, organizational processes and attributes controlled by a university that enable the university to conceive of and implement strategies that improve its efficiency and effectiveness. 


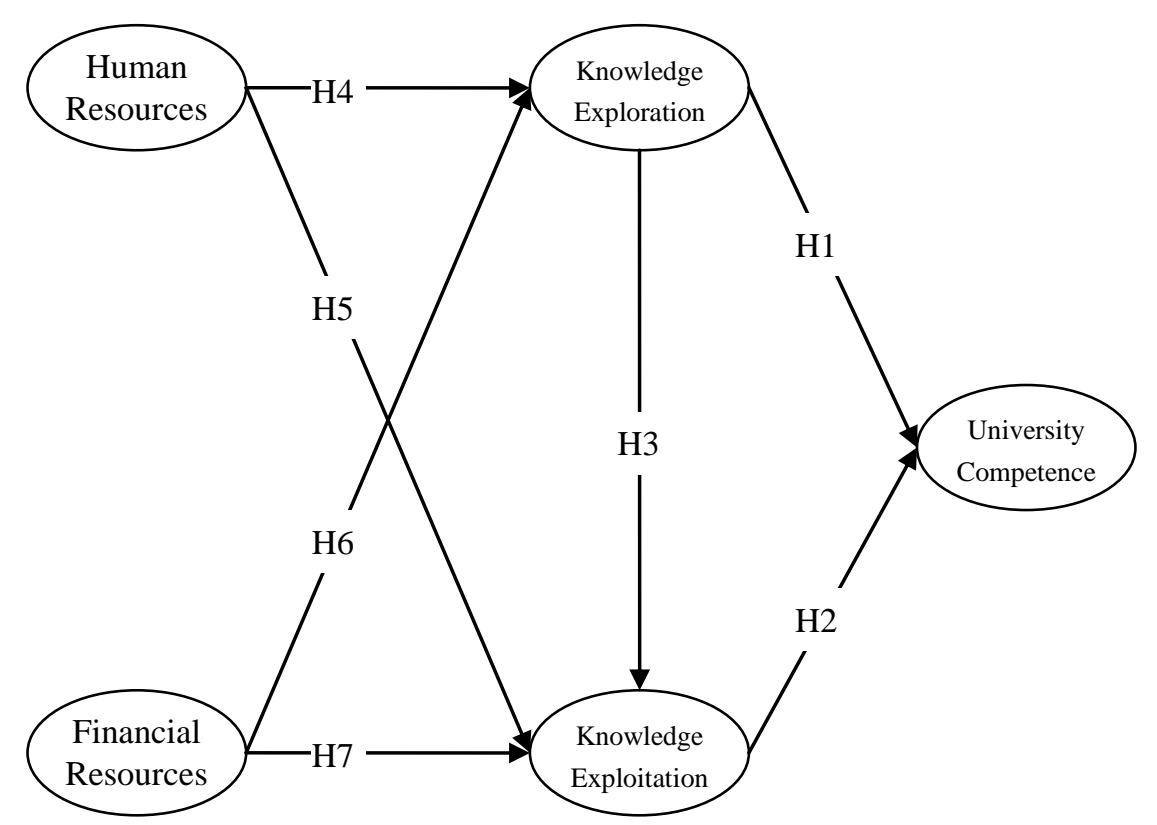

Figure 1 Research Model

\section{University Competence}

Competence is a standardized requirement for an individual to properly perform a specific job. It encompasses a combination of knowledge, skills and behavior utilized to improve performance. More generally, competence is the state or quality of being adequately or well qualified, having the ability to perform a specific role. We thus formally hypothesize the following:

H1: Knowledge exploration is positively related to university competence.

H2: Knowledge exploitation is positively related to university competence.

H3: Knowledge exploration is positively related to knowledge exploitation.

\section{University Resources}

Human resources is a term used to refer to how people are managed by organizations. The field has moved from a traditionally administrative function to a strategic one that recognizes the link between talented and engaged people and organizational success. The field draws upon concepts developed in industrial/organizational psychology and system theory. Human resources have at least two related interpretations depending on context. The original usage derives from 
political economy and economics, where it was traditionally called labor, one of four factors of production; this perspective is changing as a function of new and ongoing research into more strategic approaches at national levels. We thus formally hypothesize the following:

H4: Human resources are positively related to knowledge exploration.

H5: Human resources are positively related to knowledge exploitation.

In organizational studies, resource management is the efficient and effective deployment of an organization's resources when needed. Such resources may include financial resources, inventory, human skills, production resources, or information technology (IT). In the realm of project management, processes, techniques, and philosophies have been developed the best approach for allocating resources. Therefore, financial resources are proposed to enhance both knowledge exploration and knowledge exploitation. We thus formally hypothesize:

H6. Financial resources are positively related to knowledge exploration.

H7. Financial resources are positively related to knowledge exploitation.

\section{RESEARCH METHODOLOGY}

\section{Sample Administration}

The research model was tested with data collected from online databases and web sites. This statistical analyses focus on the 2009 Webometrics Ranking of World Universities, selecting. 124 US universities. Webometrics is an initiative of the Cybermetrics Lab, a research group of the Centro de Ciencias Humanasy Sociales (CCHS), which is part of the National Research Council of Spain. The measurement for university competence integrated university ranking and student applicant data collected from Peterson's college search (Peterson's, 2009). University ranking (reputation) data were collected from Cybermetrics Lab's report (CSIC, 2009).

The study measured knowledge exploration (academic publishing) as the number of SCI and SSCI papers published in 2007. Knowledge exploration also included highly cited researchers in subject categories as an important indicator (Shanghai, 2008). This study used the number of patent, industry funding and federal government funding for knowledge exploitation (university-industry collaboration). Because it offers more detailed records, tata were obtained from the World Intellectual Property Organization 
(WIPO, 2009), a specialized agency of the United Nations dedicated to developing a balanced and accessible international intellectual property (IP) system, rather than the United States Patent and Trademark Office (USPTO). . Industry funding and federal government funding data were collected from National Science Foundation Science and Engineering Statistics (NSF, 2007). The university resources data were also collected from Peterson's college search(Peterson's, 2009).

\section{DATA ANALYSIS}

Structural Equation Modeling (SEM) was adopted for the causal relationships data analyses between the constructs. SEM analysis was chosen over regression analysis, because SEM can analyze all paths in one analysis (Barclay et al., 1995; Gefen et al., 2000). The Partial Least Squares (PLS) approach was superior to other SEM approaches for this study because of its flexibility for distributional assumptions, its small sample size requirements, and its strength in handling complex predictive models (Fornell \& Bookstein, 1982; Hulland, 1999; Ko et al., 2005). Because this study aims at theory development instead of theory testing (Komiak \& Benbasat, 2006), the computer program used for this analysis was SmartPLS version 3.0. Since it supports exploratory research, PLS was used as the research model proposed, since it is consistent with all currently available theoretical knowledge and collect data to test the theory (Marcoulides \& Saunders, 2006).

The data analysis procedure with PLS suggested by Hulland (1999) was followed, and a bootstrapping method (Efron and Gong, 1983) was used to determine the significance of the paths within the structural model. Standard errors of parameters were computed based on 500 bootstrapping runs. To estimate the significance of the path coefficients, we used a sample size of 500, as recommended by Chin (1998).

The sample size is 124 exceeded the recommended minimum of 50, which represented 10 times of the number of items comprising the most complex constructs or the number of independent constructs directly influencing a dependent construct (Barclay et al., 1995; Wixom \& Watson, 2001). According to Hulland's (1999) procedure, a PLS model is analyzed and interpreted in two stages. First, the measurement model must be tested by performing validity and reliability analyses on each of the measures of the model to ensure that only reliable and valid measures of the constructs are used before conclusions about the nature of the constructs relationships are drawn (Hulland, 1999). Second, the structural model is tested by estimating the paths between the constructs in 
the model, determining their significance as well as the predictive ability of the model.

\section{Reliability and Convergent Validity}

The adequacy of the measurement models was evaluated on the criteria of reliability, convergent validity, and discriminant validity. Reliability and validity were tested with regard to individual item reliability, the convergent validity of the measures associated with individual constructs, and discriminant validity. First, reliability was examined using the composite reliability values. Table 1 shows that all values are above 0.8 , which is the commonly accepted level for explanatory research. The convergent validity of the scales was verified using two criteria suggested by Fornell and Larcker (1981): (1) all indicator loadings should be significant and exceed 0.7; and (2) the average variance extracted (AVE) by each construct should exceed the variance due to measurement error for that construct (i.e., AVE should exceed 0.50). For the current measurement model, all indicator loadings were above the 0.76 (see Table 2). AVE ranged from 0.66 to 0.86 (see Table 1). Hence, both conditions for convergent validity were met.

\section{Table 1 Reliability and Convergent Validity}

\begin{tabular}{lcccc}
\hline Constructs & AVE & Composite Reliability & R Square & Cronbach's Alpha \\
\hline Competence & 0.70 & 0.82 & 0.36 & 0.58 \\
Finance & 0.68 & 0.81 & & 0.55 \\
Human & 0.86 & 0.92 & & 0.84 \\
Exploitation & 0.66 & 0.85 & 0.50 & 0.74 \\
Exploration & 0.86 & 0.95 & 0.40 & 0.92 \\
\hline
\end{tabular}

\section{Discriminant Validity}

Discriminant validity implies that measures of a given construct differ from one another (Hulland, 1999). The discriminant validity of the scales was assessed using the guideline suggested by Fornell and Larcker (1981); that is, the square root of the AVE from the construct should be greater than the correlation shared between that construct and others in the model. Table 3 lists the correlations between the constructs, with the square root of the AVE on the diagonal. All of the diagonal values exceed the inter-construct correlations; hence, the test for discriminant validity was acceptable. Therefore, we conclude that the scales should have sufficient construct validity. 
Table 2 PLS Confirmatory Factor Analysis and Cross-loadings

\begin{tabular}{lccccc}
\hline & Competence & Finance & Human & Exploitation & Exploration \\
\hline Applications & $\mathbf{0 . 7 7}$ & 0.32 & 0.51 & 0.29 & 0.40 \\
Ranking & $\mathbf{0 . 9 0}$ & 0.58 & 0.45 & 0.50 & 0.54 \\
\hline Collection & 0.44 & $\mathbf{0 . 7 3}$ & 0.35 & 0.29 & 0.43 \\
Research Budget & 0.49 & $\mathbf{0 . 9 1}$ & 0.44 & 0.64 & 0.54 \\
\hline Faculty & 0.52 & 0.32 & $\mathbf{0 . 9 1}$ & 0.27 & 0.38 \\
Professor & 0.52 & 0.55 & $\mathbf{0 . 9 4}$ & 0.34 & 0.49 \\
\hline Industry & 0.30 & 0.51 & 0.22 & $\mathbf{0 . 7 8}$ & 0.45 \\
Federal government & 0.42 & 0.47 & 0.26 & $\mathbf{0 . 8 6}$ & 0.69 \\
Patent & 0.48 & 0.49 & 0.31 & $\mathbf{0 . 8 0}$ & 0.41 \\
\hline SCI & 0.50 & 0.56 & 0.41 & 0.65 & $\mathbf{0 . 9 6}$ \\
SSCI & 0.51 & 0.47 & 0.49 & 0.49 & $\mathbf{0 . 9 3}$ \\
High Cited Researcher & 0.58 & 0.60 & 0.43 & 0.65 & $\mathbf{0 . 9 0}$ \\
\hline
\end{tabular}

Table 3 Latent Variable Correlation Matrix

\begin{tabular}{lccccc}
\hline & Competence & Finance & Human & Exploitation & Exploration \\
\hline Competence & $\mathbf{0 . 8 3}$ & & & & \\
Finance & 0.56 & $\mathbf{0 . 8 2}$ & & & \\
Human & 0.56 & 0.48 & $\mathbf{0 . 9 3}$ & & \\
Exploitation & 0.49 & 0.60 & 0.33 & $\mathbf{0 . 8 1}$ & \\
Exploration & 0.58 & 0.59 & 0.47 & 0.65 & $\mathbf{0 . 9 3}$ \\
\hline
\end{tabular}

Note: Square root of AVE is on the diagonal

\section{Path Coefficients and Predictive Ability}

The assessment of the structural model involves estimating the path coefficients and the $\mathrm{R}^{2}$ value. The path coefficients indicate the strengths of the relationships between the independent and dependent variables, whereas the $\mathrm{R}^{2}$ value is a measure of the predictive power of a model for the dependent variables. Table 4 and Figure 2 show the path coefficients, their significance level and the $\mathrm{R}^{2}$ values of the endogenous variables. The PLS analysis results (Figure 2) show that only one hypothesis has a negative effect and the other hypotheses are supported, thus the proposed theoretical model in Figure 1 is partially supported. In this study, the model accounts for 35.6 to 49.8 percent of the variances $\left(\mathrm{R}^{2}\right.$ scores). In addition, most of the paths are significant at the 0.05 level (Figure 2); one path (human resource to knowledge exploitation) is not significant. Thus, the fit of the overall model is good. Knowledge exploration and knowledge exploitation 
will both enhance competence in the university $(\beta=0.44, p<0.01 ; \beta=0.21, p<0.05)$. Thus, it can be concluded that the hypothesized model is partially supported by the data.

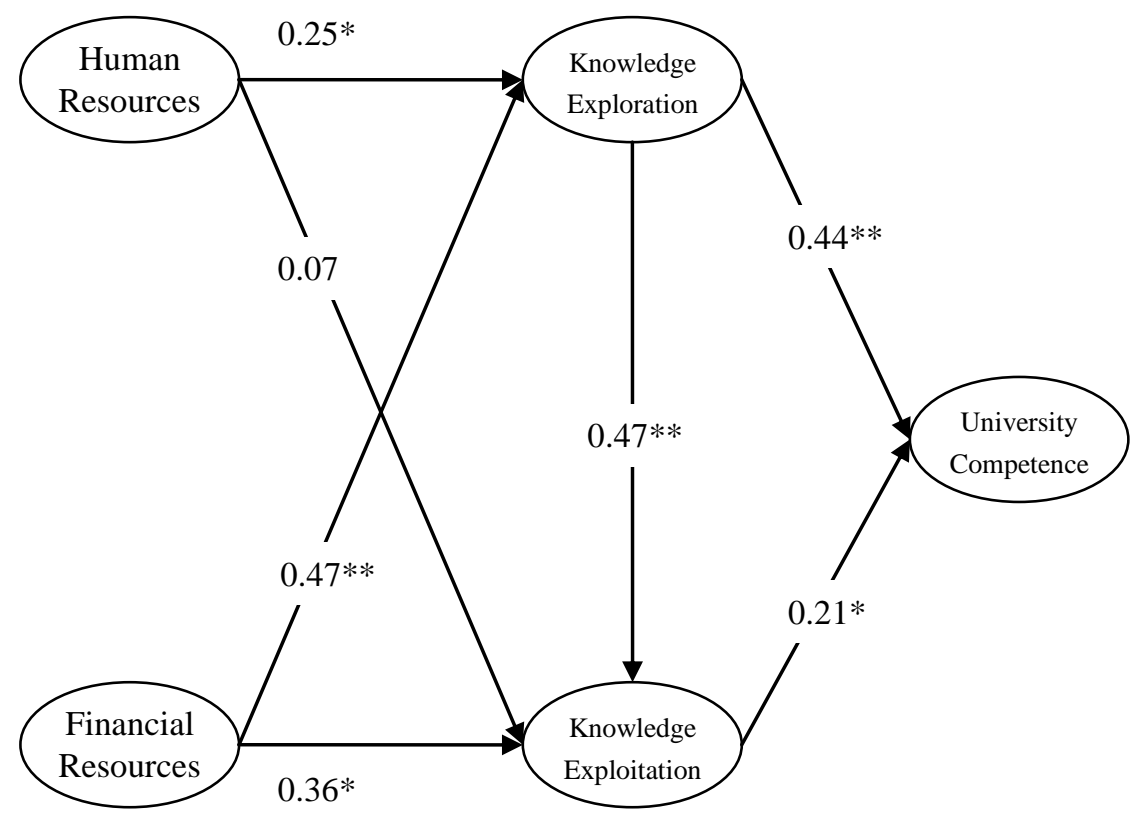

Figure 2 Hypotheses Testing Results

\section{DISCUSSION}

American research universities are now experimenting with new mechanisms for promoting the commercialization of academic research and generating revenue from university intellectual property (Feldman, Feller, Bercovitz, \& Burton, 2002). This paper aims to shed light on the phenomenon of research performance in the university. Drawing on resource-based and resource-dependence literature, the study theoretically develops and empirically tests a model that explains university resources play an important role in the university research performance.

This study explores the relationship between university resources and its research performance in the resource-based view. Results indicate that research performance of the universities should balance the knowledge exploration with knowledge exploitation in order to increase the university's competence. University resources can be separated as human and financial resources. Both play important roles and will improve knowledge exploration. University resources, especially human resources, are also important for 
supporting academic publishing for scholars. Moreover, improving knowledge exploitation depends on financial resources. Finally, knowledge exploration is an important factor to enhance knowledge exploitation. Previous studies found that human resource (HR) practices influence knowledge exploration and exploitation practices (Donate \& Guadamillas, 2011). In this study, knowledge exploitation represents university-industry collaboration.

Table 4 Summary of the Hypothesis Test Results

\begin{tabular}{lcccc}
\hline Casual Path & Hypothesis & Path Coefficients & t-Value & Supported \\
\hline Exploration-> Competence & H1 & 0.44 & $4.60^{\mathrm{b}}$ & Yes \\
Exploitation-> Competence & $\mathrm{H} 2$ & 0.21 & $2.08^{\mathrm{a}}$ & Yes \\
Exploration-> Exploitation & $\mathrm{H} 3$ & 0.47 & $3.99^{\mathrm{b}}$ & Yes \\
Human -> Exploration & $\mathrm{H} 4$ & 0.27 & $2.34^{\mathrm{a}}$ & Yes \\
Human -> Exploitation & $\mathrm{H} 5$ & -0.07 & 0.65 & No \\
Finance -> Exploration & $\mathrm{H} 6$ & 0.47 & $3.53^{\mathrm{b}}$ & Yes \\
Finance -> Exploitation & $\mathrm{H} 7$ & 0.36 & $2.57^{\mathrm{a}}$ & Yes \\
\hline
\end{tabular}

${ }^{a}$ Significant at $\mathrm{p}<0.05$ level.

${ }^{\mathrm{b}}$ Significant at $\mathrm{p}<0.01$ level.

\section{CONCLUSION}

The present study provides a more detailed examination of university research performance. In terms of theory building, this study attempts to develop an appropriate model to examine the relationship between research performance and university resources. The study extends the resource-based literature from profit organization to a scholarly context. A major finding is the dominant roles of human resources and financial resources in forming research performance, which in turn has a strong positive influence on university competence. Consequently, both human resources and financial resources provide an adequate explanation of research performance. Furthermore, the samples used in this study are not representative of the whole population. Therefore, the generalizability of the findings is limited. However, this research still offers valuable insights into university research performance. There are some limitations to the current study, which suggest directions for possible extensions, such as the impact of social responsibility from the university. 


\section{REFERENCES}

Amit, R. \& Schoemaker Paul, J.H. (1993). Strategic assets and organizational rent. Strategic Management Journal, 14(1), 33-46. doi:10.1002/smj.4250140105.

Barclay, D., Higgins, C., \& Thompson, R. (1995). The partial least squares (PLS) approach to causal modeling: Personal computer adoption and use as an illustration. Technology studies, 2(2), 285-309.

Barney, J. (1991). Firm resources and sustained competitive advantage. Journal of Management, 17(1), 99-120. doi:10.1177/014920639101700108.

Birger, W. (1984). A resource-based view of the firm. Strategic Management Journal, 5(2), 171-180.

Chin, W.W. (1998). Issues and opinion on structural equation modeling. MIS Quarterly, 22(1), vii-xvi.

CSIC, C.L. (2009). World universities' ranking on the Web. Retrieved June 14, 2012, from http://www.webometrics.info/

Donate, M.J. \& Guadamillas, F. (2011). Organizational factors to support knowledge management and innovation. Journal of Knowledge Management, 15(6), 890-914. doi:10.1108/13673271111179271.

Efron, B., \& Gong, G. (1983). A leisurely look at the bootstrap, the jackknife, and cross-validation. The American Statistician, 37(1), 36-48. doi:10.2307/2685844.

Feldman, M., Feller, I., Bercovitz, J., \& Burton, R. (2002). Equity and the technology transfer strategies of American research universities. Management Science, 48(1), 105-121. doi:10.1287/mnsc.48.1.105.14276.

Fornell, C., \& Bookstein, F.L. (1982). Two structural equation models: LISREL and PLS applied to consumer exit-voice theory. Journal of Marketing Research, 19(4), 440-452. doi:10.2307/3151718.

Fornell, C., \& Larcker, D.F. (1981). Evaluating structural equation models with unobservable variables and measurement error. Journal of Marketing Research, 18(1), 39-50. doi:10.2307/3151312.

Gefen, D., Straub, D., \& Boudreau, M.C. (2000). Structural equation modeling and regression: Guidelines for research practice. Communications of the Association for Information Systems, 4(1), 1-70.

Grant, R.B. (1991). A resource based theory of competitive advantage: Implications for strategy formulation. California Management Review, 33(3), 114-135. doi:10.2307/41166664. 
Hillman, A.J., Withers, M.C., \& Collins, B.J. (2009). Resource dependence theory: A review. Journal of Management, 35(6), 1404-1427. doi:10.1177/0149206309343469.

Himanen, L., Auranen, O., Puuska, H.-M., \& Nieminen, M. (2009). Influence of research funding and science policy on university research performance: A comparison of five countries. Science and Public Policy, 36(6), 419-430. doi:10.3152/030234209X461006.

Hulland, J. (1999). Use of partial least squares (PLS) in strategic management research: a review of four recent studies. Strategic Management Journal, 20(2), 195-204. doi:10.1002/(SICI)1097-0266(199902)20:2<195::AID-SMJ13>3.3.CO;2-Z.

Ko, D.G., Kirsch, L.J., \& King, W.R. (2005). Antecedents of knowledge transfer from consultants to clients in enterprise system implementations. MIS Quarterly, 29(1), 59-85.

Komiak, S.Y.X., \& Benbasat, I. (2006). The effects of personalization and familiarity on trust and adoption of recommendation agents. MIS Quarterly, 30(4), 941-960.

March, J.G. (1991). Exploration an exploitation in organisational learning. Organization Science, 2(1), 71-87. doi:10.1287/orsc.2.1.71.

March, J.G., \& Sutton, R.I. (1997). Crossroads - organizational performance as a dependent variable. Organization science, 8(6), 698-706. doi:10.1287/orsc.8.6.698.

Marcoulides, G.A., \& Saunders, C. (2006). Editor's comments: PLS: a silver bullet? MIS Quarterly, 30(2), iii-ix.

Marginson, S. (2006). Dynamics of national and global competition in higher education. Higher Education, 52(1), 1-39. doi:10.1007/s10734-004-7649-х.

Mintzberg, H. (1989). The professional organization. New York: Free Press. doi:10.1086/224616.

Mowery, D.C., Nelson, R.R., Sampat, B.N., \& Ziedonis, A.A. (2001). The growth of patenting and licensing by U.S. universities: An assessment of the effects of the Bayh-Dole act of 1980. Research Policy, 30(1), 99-119. doi:10.1016/S0048-7333(99)00100-6.

Nemati, A.R., Bhatti, A.M., Maqsal, M., Mansoor, I., \& Naveed, F. (2010). Impact of resource based view and resource dependence theory on strategic decision making. International Journal of Business and Management, 5(12), 110-115.

NSF. (2007). Survey of Research and Development Expenditures at Universities and Colleges. $\quad$ Retrieved June 14, 2012, from 
http://www.nsf.gov/statistics/srvyrdexpenditures/

Pfeffer, J. (1981). Power in organizations. Marshfield, MA: Pitman. doi:10.1017/CBO9780511626562.003.

Penrose, E.T. (1995). The theory of the growth of the firm. New York: Oxford University Press. doi:10.1016/S0024-6301(96)90295-2.

Peteraf, M.A. (1993). The cornerstones of competitive advantage: A resource-based view. Strategic management journal, 14(3), 179-191. doi:10.1002/smj.4250140303.

Peterson's, A.N.C. (2009). Peterson's college search. Retrieved June 14, 2012, from http://www.petersons.com

Pfeffer, J. \& Salancik, G.R. (1978). The external control of organizations: A resource dependence perspective. New York: Harper and Row.

Priem, R.L. \& Butler, J.E. (2001). Is the resource-based" view" a useful perspective for strategic management research? Academy of management review, 26(1), 22-40. doi:10.5465/AMR.2001.4011928.

Rosenberg, N. \& Nelson, R.R. (1994). American universities and technical advance in industry. Research Policy, 23(3), 323-348. doi:10.1016/0048-7333(94)90042-6.

Shanghai, U.J.T. (2008). Academic ranking of world universities. Retrieved June 14, 2012, from http://www.arwu.org/rank2008/ARWU2008Methodology(EN).htm

Trieschmann, J.S., Dennis, A.R., Northcraft, G.B., \& Nieme Jr, A.W. (2000). Serving Constituencies in Business Schools: M.B.A. Program Versus Research Performance. Academy of Management Journal, 43(6), 1130-1141. doi:10.2307/1556341.

Tsui, A.S. (1990). A multiple-constituency model of effectiveness: An empirical examination at the human resource subunit level. Administrative Sciences Quarterly, 35(3), 458-483. doi:10.2307/2393313.

Wernerfelt, B. (1984). A resource-based view of the firm. Strategic management journal, 5(2), 171-180. doi:10.1002/smj.4250050207.

WIPO. (2009). World Intellectual Property Organization Patent Search. Retrieved June 14, 2012, from http://www.wipo.int/

Wixom, B.H., \& Watson, H.J. (2001). An empirical investigation of the factors affecting data warehousing success. MIS Quarterly, 25(1), 17-32. doi:10.2307/3250957.

Zammuto, R.F. (1984). A comparison of multiple constituency models of organizational effectiveness. Academy of Management Review, 9(4), 606-616. doi:10.2307/258484. 
$\underline{\text { International Journal of Cyber Society and Education } 126}$ 